\title{
Perawatan apeksifikasi pada gigi permanen muda insisivus pertama kiri atas yang non-vital Apexification treatment of non-vital young permanent left central insicivus
}

\author{
${ }^{1}$ Jenny Krisnawaty, ${ }^{2}$ Moch. Richata Fadil, ${ }^{2}$ Endang Sukartini, ${ }^{2}$ Milly Armilia \\ ${ }^{1}$ Program Pendidikan Dokter Gigi Spesialis Konservasi Gigi \\ ${ }^{2}$ Bagian Konservasi Gigi \\ Fakultas Kedokteran Gigi Universitas Padjajaran \\ Bandung, Indonesia
}

\begin{abstract}
Imperfect young permanent teeth caused by caries or trauma could become necrotic before it's growth and development completed, thus causes imperfect shape of the root canal and an opened apex. Difficulty in treatment of root canal caused by the absence of apical stop, that makes obturation cannot be accomplished because filling materials will be pushed to periapex. The purpose of this case report was to report the treatment of anterior teeth which diagnosed as necrotic with apexification. The material filling is calcium hydroxide with strong base nature and give antimicrobacterial effect and tissue liquefaction. The result of the treatment was closure of the apex, the tissue surrounding tooth is in normal range or that absence of radiolusency which is a sign of healing at the periapical.The conclusion is young permanent tooth which experienced pulp necrotic can be treated with apexification treatment.
\end{abstract}

Key words: young permanent tooth, necrotic pulp, apexification

\begin{abstract}
ABSTRAK
Gigi permanen muda yang mengalami kerusakan karena karies atau trauma dapat berakibat nekrotik sebelum perkembangan dan pertumbuhan akar selesai, sehingga menyebabkan saluran akar tidak terbentuk sempurna dan apeks terbuka. Kesulitan dalam melakukan perawatan saluran akar gigi tersebut karena tidak adanya apical stop, sehingga obturasi tidak dapat dilakukan karena bahan pengisi akan terdorong ke periapikal. Tujuan dan perawatan pada gigi anterior dengan diagnosis nekrosis adalah untuk tercapainya saluran akar yang menutup apikal akar dengan deposit jaringan keras, dengan cara apeksifikasi. Obat yang digunakan adalah kalsium hidroksid dengan sifat basa kuat dan dapat memberikan efek antimikroba serta mampu melarutkan jaringan. Hasil yang dicapai adalah terjadi penutupan apeks gigi, jaringan lunak di sekitar gigi dalam keadaan normal atau tidak dijumpai adanya gambaran radiolusen yang merupakan tanda patologis di bagian periapikal. Setelah dilakukan perawatan apeksifikasi pada gigi permanen muda yang mengalami nekrosis, dsimpulkan bahwa hasil perawatan memperlihatkan keberhasilan yang ditandai dengan penutupan foramen apikal, jarinan lunak di sekitar gigi normal dan radiologis tidak dijumpai gambaran radiolusen.
\end{abstract}

Kata kunci: gigi permanen muda, nekrosis pulpa, perawatan apeksifikasi

Koresponden: Jenny Krisnawaty, Jl. Tanoh Abe No.4, Kampung Mulia-Banda Aceh, Indonesia. E-mail: jennykrisnawaty@yahoo.com

\section{PENDAHULUAN}

Gigi permanen muda adalah gigi permanen yang saluran akar belum terbentuk sempurna. Gigi tersebut dapat mengalami nekrosis yang disebabkan oleh kelainan pulpa maupun periapikal atau akibat adanya trauma pada gigi, sehingga pertumbuhan akar terhenti. Apeks akan tetap terbuka dan saluran akar lebih lebar di bagian apeks dibanding dengan daerah serviks. Karena apeks masih terbuka lebar, perawatan endodontik konvensional menjadi sulit dan keberhasilannya tidak dapat diperkirakan. ${ }^{1}$

Untuk mengatasi masalah ini digunakan teknik apeksifikasi, yaitu teknik perawatan endodontik dengan tujuan untuk menutup foramen apikal dengan jaringan keras sebagai barrier pada gigi permanen muda dengan akar yang belum terbentuk sempurna. Perawatan gigi non vital dengan apeks terbuka pada prinsipnya tidak berbeda dengan perawatan endodontik gigi non vital, yaitu meliputi pembersihan dan pembentukan saluran akar, disinfeksi saluran akar, dan obturasi saluran akar dengan bahan pengisi. Penutupan apeks dapat dilakukan dengan tindakan bedah maupun secara konvensional. Prosedur endodontik ini memerlukan pembersihan saluran akar secara kemomekanis diikuti dengan pemberian obat-obatan intrakanal untuk membantu atau merangsang penutupan apeks dan membentuk apeks barrier. ${ }^{2}$

Apeksifikasi adalah suatu tahap perawatan endodontik yang mempunyai tujuan merangsang perkembangan lebih lanjut proses penutupan apeks gigi yang belum tumbuh sempurna, tetapi telah mengalami kematian pulpa dengan membentuk suatu semen sekunder pada apeks gigi tersebut. ${ }^{3,4}$ 
Perawatan untuk terjadinya apeksifikasi merupakan suatu perawatan saluran akar untuk membantu penutupan apeks gigi yang belum sempurna pada pulpa non vital terbuka tanpa disertai kelainan periapikal dengan pembentukan osteodentin atau substansi lainnya.Apeksifikasi sejatinya merupakan perawatan pendahuluan sebelum pengisian saluran akar pada perawatan endodontik intrakanal. Tujuan apeksifikasi adalah merangsang pembentukan calcific barrier pada $1 / 3$ apeks yang masih terbuka lebar. ${ }^{4}$

Penulisan laporan ini dimaksudkan untuk membahas perawatan apeksifikasi pada gigi permanen muda insisivus pertama kiri atas yang non-vital

\section{KASUS}

Seorang anak laki-laki berusia 13 tahun datang ke Klinik Spesialis Konservasi Gigi Rumah Sakit Gigi dan Mulut berdasarkan rujukan dari Pusat Pelayanan Kesehatan Gigi dan Mulut Bandung, dengan maksud untuk memperbaiki gigi yang patah. Berdasarkan anamnesis diketahui gigi patah karena jatuh 3 bulan yang lalu, dan pasien menyatakan tidak pernah ada keluhan nyeri atau pembengkakan.

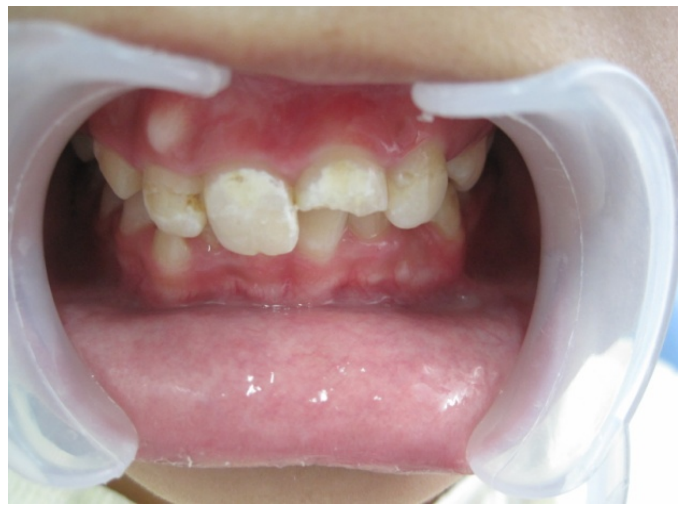

Gambar 1 Gambaran klinis tampak dari depan
Pada pemeriksaan klinis tampak gigi 21 mengalami fraktur sampai sepertiga mahkota (Gambar 1). Kamar pulpa terbuka dan gigi telah berubah warna menjadi lebih gelap. Tes perkusi dan palpasi tidak memberikan respon positif. Pemeriksaan radiografis menunjukkan saluran akar lebar dan apeks terbuka (Gambar 2A).

Diagnosis gigi 21 adalah nekrosis pulpa dengan apeks terbuka. Rencana perawatan gigi 21 adalah apeksifikasi dengan menggunakan kalsium hidroksida $(\mathrm{CaOH})_{2}$, dan restorasi komposit yang diperkuat dengan pasak fiber.

\section{PENATALAKSANAAN}

Pada kunjungan pertama dilakukan preparasi akses. Kemudian dilakukan pengukuran panjang kerja dengan hasil sepanjang $21 \mathrm{~mm}$, dilanjutkan dengan ekstirpasi, reaming dan filing sesuai dengan panjang kerja. Saluran akar kemudian diirigasi dengan larutan natrium hipoklorit 2,5\%. Setelah itu diirigasi kembali dengan cairan akuades, kemudian dibilas dengan EDTA 17\% untuk membuang smear layer. Setelah saluran akar dikeringkan dengan paper point, pasta kalsium hidroksida $(\mathrm{CaOH})_{2}$ diaplikasikan sampai apikal, kemudian dilakukan foto radiografi (Gambar 2B).

Pada kunjungan kedua dilakukan kontrol, pasien tidak mengeluhkan adanya gejala klinis dan tes perkusi negatif. Selanjutnya, dilakukan penggantian kalsium hidroksida karena kalsium hidroksida mengalami pelarutan sehingga tidak mengeras. Saluran akar kemudian ditutup dengan semen glass ionomer.

Pada kunjungan ketiga, dilakukan kontrol lagi, pasien tidak mengeluhkan apapun saat dilakukan pemeriksaan perkusi dan palpasi. Pada pemeriksaan radiografi terlihat adanya jaringan keras pada ujung akar. Untuk meyakinkan pemeriksaan, dilakukan pemeriksaan klinis dan digunakan jarum $K$-file
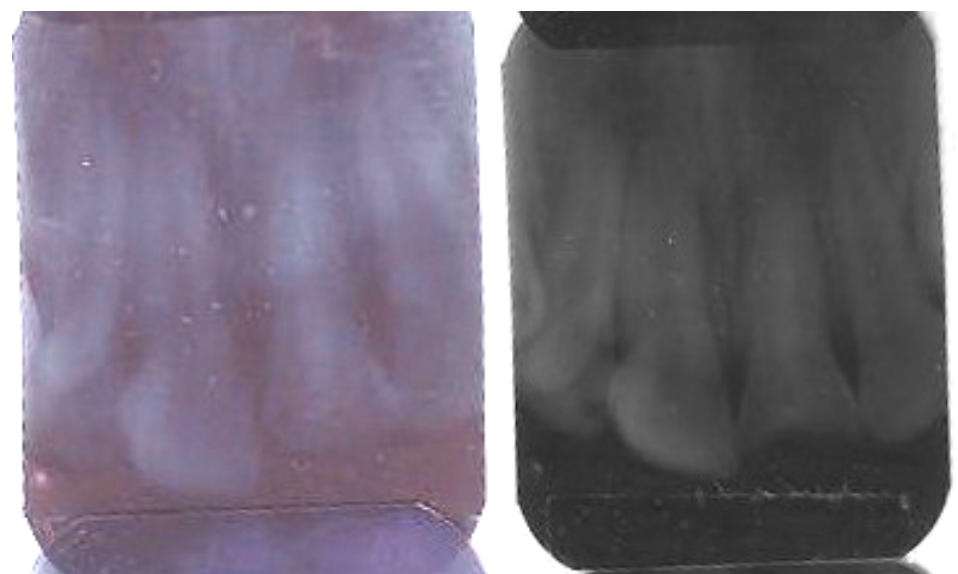

Gambar 2A Gambaran radiografis gigi 21, B foto pengisian kalsium hidroksida pada kunjungan pertama 
berukuran 80 untuk pemeriksaan ada tidaknya sumbatan, kemudian dilakukan trial pengisian. Pada kunjungan ini dibuat foto trial master apical cone dengan gutta percha no.80 sepanjang $21 \mathrm{~mm}$ (Gambar 3A). Bentuk saluran akar yang terbentuk memungkinkan dilakukan pengisian saluran akar secara kondensasi lateral dengan menggunakan sealer endomethasone (Gambar 3B). Saluran akar kemudian ditutup dengan semen glass ionomer.

Pada kunjungan keempat dilakukan kontrol pengisian (Gambar 4A), pasien tidak mengeluhkan apapun pada pemeriksaan palpasi dan perkusi, foto ronsen tidak memperlihatkan kelainan di saluran akar dan di daerah sekitar apeks. Selanjutnya dilakukan preparasi pada mahkota untuk restorasi dengan pasak fiber dan direct composit, dilanjutkan sementing pasak dan tumpatan komposit (Gambar 4B). Pada kunjungan kelima, dilakukan kontrol dengan hasil pasien menyatakan tidak ada keluhan, dan tumpatan masih terpasang dengan baik.

\section{PEMBAHASAN}

Pada kasus pasien ini, adanya fraktur mahkota, perubahan warna gigi dan kondisi apeks terbuka disebabkan oleh karena trauma akibat terjatuh yang terjadi beberapa bulan sebelumya pada saat gigi belum mature dan apeks masih terbuka. Pulpa menjadi nekrosis sebelum pertumbuhan akar selesai, dan sebagai akibatnya pembentukan dentin menjadi terhenti.

Pada saat pasien datang pertama kali, secara radiografis tampak apeks akar gigi sudah mulai menyempit tetapi apeks masih terbuka memberikan prognosis yang baik bagi perawatan karena luas daerah apeks yang terbuka tidak begitu besar. Diharapkan bila kemudian terjadi penutupan apeks, kemungkinan kebocoran apikal bisa lebih kecil, dibandingkan dengan apeks yang masih terbuka lebar.

Pada pasien ini dilakukan perawatan apeksifikasi, dengan harapan saluran akar terbuka akan menutup. Kalsium hidroksida yang berkontak dengan jaringan akan menyebabkan inflamasi pada daerah yang berkontak. Jaringan lunak akan mengalami distrofi kalsifik, dan terjadi deposisi jaringan keras. $^{2}$
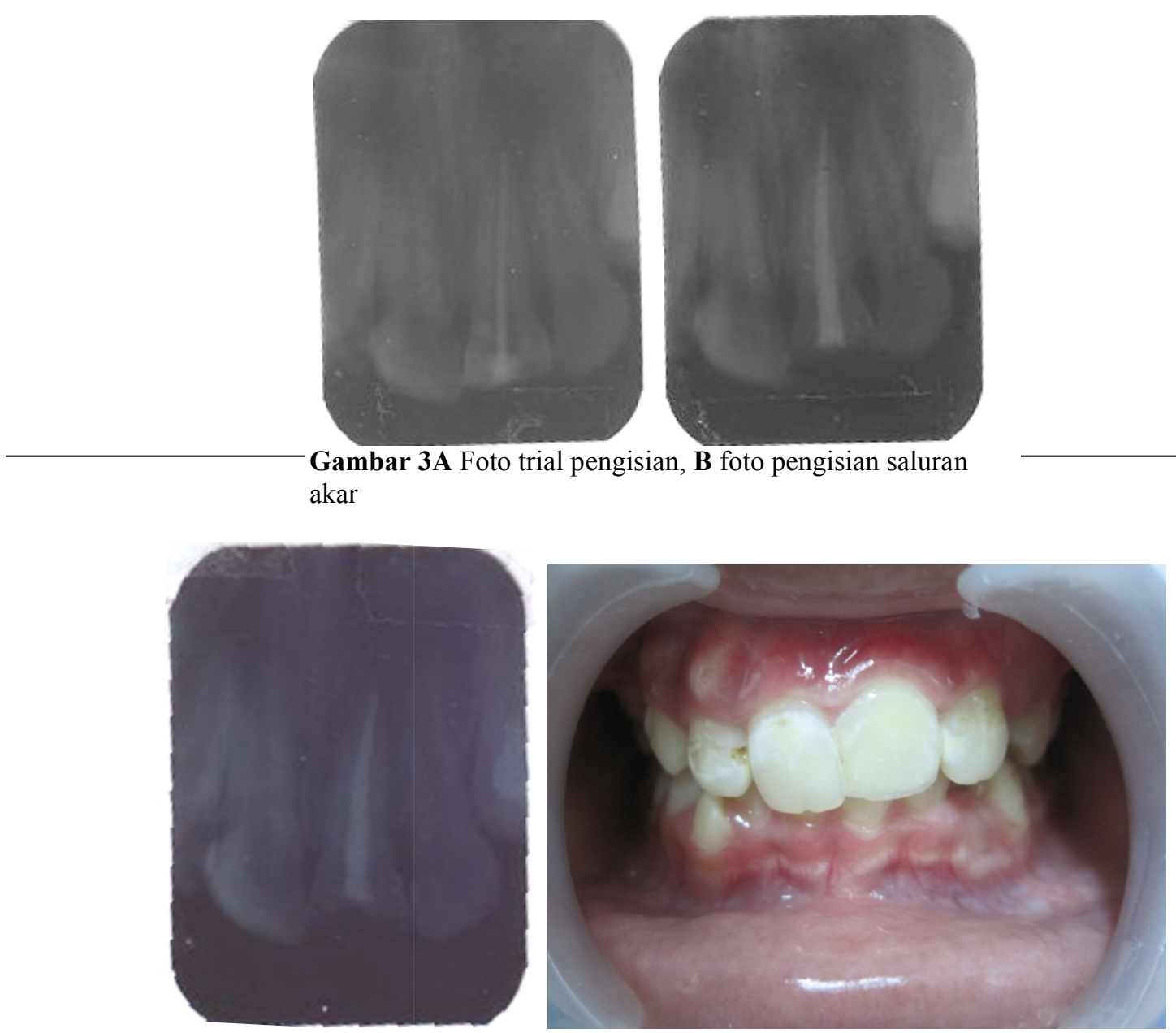

Gambar 4 Foto kontrol pengisıan saluran akar, B Restorasi direct composit dengan pasak fiber pada gigi 21 
Pada kunjungan ketiga (bulan ketiga), tampak apeks sudah menutup, tidak ada kelainan jaringan periapikal dan panjang saluran akar bertambah. Saluran akar tidak terlihat menyempit. Hal ini mungkin terjadi karena masih terdapatnya selubung epitel akar Hertwig atau sisa jaringan pulpa yang masih vital di daerah apeks sehingga pembentukan apeks dapat terus berlanjut, ditandai dengan bentuk apeks yang mengecil menyerupai bentuk normal apeks dan bertambahnya panjang akar.

Kalsium hidroksida diaplikasikan ke dalam saluran akar untuk jangka waktu yang lama, yaitu antara 6-24 bulan, sampai terbentuk barrier apikal yang cukup kuat untuk dilakukan obturasi saluran akar. ${ }^{3,4}$ Kurimoto mengemukakan terjadinya aposisi sementum pada lesi periapikal setelah penggunaan $\mathrm{Ca}(\mathrm{OH})_{2}$. Kaiser mengemukakan terjadinya induksi jaringan keras pada apeks yang terbuka setelah penggunaan $\mathrm{Ca}(\mathrm{OH})_{2}$ jangka panjang. ${ }^{4}$ Kennedy dkk, Kennedy dan Simpson malah membuktikan kemampuan $\mathrm{Ca}(\mathrm{OH})_{2}$ menyembuhan lesi periapikal dengan membentuk barrier kalsifik pada apeks. ${ }^{5}$

Pada apeksifikasi, $\mathrm{Ca}(\mathrm{OH})_{2}$ berkontak dengan jaringan periodontal atau jaringan granulasi. Dalam hal ini, jaringan keras yang terbentuk dapat berbentuk jaringan yang menyerupai sementum; berupa massa padat yang termineralisasi; berbentuk massa yang bentuknya tidak beraturan dan kadang terdapat jaringan lunak diantaranya. ${ }^{4}$

Setelah saluran akar diirigasi dan dikeringkan, dilakukan pengisian dengan $\mathrm{Ca}(\mathrm{OH})_{2}$ dalam bentuk pasta sesuai panjang kerja. Saat ini sudah tersedia $\mathrm{Ca}(\mathrm{OH})_{2}$ siap pakai dan mudah pengaplikasiannya. Untuk mendapatkan hasil apeksifikasi yang baik, kalsium hidroksida harus dipadatkan hingga berkontak langsung dengan jaringan periapikal. Kondensasi kalsium hidroksida dilakukan dengan menggunakan ujung gutta percha atau dengan plugger. Penggunaan alat dan tekanan pada saat kondensasi harus hati-hati karena dinding saluran akar tipis dan mudah. ${ }^{1,2,4}$

Penggantian $\mathrm{Ca}(\mathrm{OH})_{2}$ perlu dilakukan bila terjadi pengenceran kalsium hidroksida karena terjadi eksudasi jaringan periapikal maupun bila terjadi kebocoran korona. Kontrol secara periodik lebih banyak dilakukan pada bulan pertama, yaitu setiap1-2 minggu sampai tidak terjadi pengenceran kalsium hidroksida. Setelah itu dilakukan observasi pada bulan ke 3,6 dan 12 .

Keberhasilan apeksifikasi dapat diketahui dari hasil pemeriksaan radiografis. Pada bulan keenam dapat dilakukan evaluasi gambaran radiografis. Ada lima kemungkinan kondisi apikal yang terjadi, pertama secara radiografis tidak tampak adanya perubahan, tetapi bila instrumen dimasukkan ke dalam saluran akar akan terasa tahanan pada apeks, kedua terlihat adanya massa terkalsifikasi di sekitar atau pada apeks, ketiga apeks tampak tertutup tanpa adanya perubahan pada ruangan saluran akar, keempat apeks terus terbentuk dengan penyempitan saluran akar, dan kelima sama sekali tidak terlihat perubahan secara radiografis, gejala klinis masih tetap ada, dan terjadi pembentukan lesi periapikal atau lesi periapikal menjadi lebih besar. ${ }^{1}$

Saluran akar siap untuk diobturasi bila salah satu dari empat kondisi pertama seperti tersebut di atas sudah tercapai. Saluran akar dapat diobturasi sampai ke apeks yang terbentuk atau sampai ke stop kalsifik. Bila tidak terjadi perbaikan, maka perawatan apeksifikasi harus diulang. ${ }^{1}$

Tingkat keberhasilan perawatan apeksifikasi adalah $74-100 \%$ dalam jangka waktu 10 tahun atau lebih. Kegagalan perawatan dapat terjadi beberapa saat setelah perawatan. Penyebabnya antara lain karena adanya kebocoran korona maupun apeks, apeks belum tertutup dengan baik, atau karena perawatan endodontik yang kurang baik. Barrier apikal merupakan massa padat yang relatif lebih porus dibandingkan dengan dentin atau sementum, maka kebocoran dari arah apikal masih dapat terjadi. ${ }^{1,3,4}$

Dari penangan kasus ini, disimpulkan bahwa apeksifikasi merupakan tahapan pendahuluan pada perawatan endodontik. Keberhasilan apeksifikasi ditandai dengan terbebasnya pasien dari rasa nyeri spontan dan gambaran radio-opak di daerah apeks yang berarti terjadinya penutupan apeks gigi, jaringan di sekitar gigi dalam keadaan normal dan tidak ada gambaran radiolusen di daerah apikal.

Apeksifikasi memerlukan waktu yang cukup lama, sehingga dibutuhkan suatu pengertian dan kerjasama yang baik antara pasien dan dokter gigi. Oleh karena itu dokter gigi harus memberikan informasi yang lengkap kepada pasien, mengenai tindakan, lama, tujuan dan biaya perawatan.

\section{DAFTAR PUSTAKA}

1. Weine FS. Endodontic therapy. $6^{\text {th }}$ Ed. St.Louis: CV Mosby Co; 2004. p.519-29.

2. Camp JH., Barrett EJ, Pulver F. Pediatric endodontics: endodontic treatment for the primary and young, permanent dentition In: Cohen S, Burns RC, editor. Pathways of the pulp. $8^{\text {th }}$ Ed: St.Louis: CV Mosby Co,; 2002. p.833-9.

3. Townbridge H, Kim S, Suda H. Structure and functions of the dentin and pulp complex In: Cohen S, Burns RC, editor. Pathways of the pulp. $8^{\text {th }}$ Ed. St.Louis: CV Mosby Co,; 2002. p.415. 
4. Pitt Ford TR, Shabahang S. Management of incompletely formed roots In: Walton R, Torabinejad M, editor. Principles and practice of endodontics. Philadelphia: WB Saunders; 2002. p.388-403.

5. Tronstad L. Clinical endodontics. $2^{\text {nd }}$ Rev. Stuttgart: Thieme; 2003. p.120-3.

6. Bakland LK. Endodontic considerations in dental trauma In: Ingle JI. Endodontics. $5^{\text {th }}$ Ed. Hamilton: BC Decker; 2002. p.827-9.

7. Wesselink P, Bergenholtz G. Treatment of the necrotic pulp. In: Bergenholtz G, Horsted-Bindslev P, Reit C, editor. Textbook of endodontology. Oxford: Blackwell Munksgaard; 2003. p.165-6. 